KONTINU: Jurnal Penelitian Didaktik Matematika

Vol: 2, No.2, Oktober 2018

\title{
PENERAPAN TEORI SITUASI DIDAKTIK PADA MATERI ARITMATIKA SOSIAL
}

Firda Farikhatul Inayah

Madrasah Aliyah Miftahul Ulum, Jepara

firdafaricha26@gmail.com

Sari. Penelitian ini bertujuan untuk mendeskripsikan penerapan teori situasi didaktik pada materi aritmatika sosial SMP kelas VII. Hasil penelitian dengan menggunakan teori situasi didaktik pada pembelajaran matematika menunjukkan bahwa teori situasi didaktik dapat diterima dengan baik oleh siswa, siswa dapat melaksanakan fase-fase yang ada dalam teori situasi didaktik dengan baik. Siswa mampu mengerjakan secara mandiri maupun secara bersama (kelompok). Jawaban yang diberikan siswa pada saat tes dengan menggunakan teori situasi didaktikpun bervariasi. Aktivitas siswa yang selalu meningkat pada saat pembelajaran dari pertemuan pertama sampai dengan pertemuan terakhir yaitu pertemuan ketiga terlihat dari pengamatan aktivitas siswa pada saat pembelajaran. Respon siswa terhadap pembelajaran dengan menggunakan teori situasi didaktikpun tergolong baik dibuktikan dari hasil angket siswa.

Kata Kunci: Teori Situasi Didaktik, Aritmatika Sosial

\begin{abstract}
Abstarct. This study aims to describe the application of didactic situation theory design on social arithmetic material SMP class VII.The result of research used didactic situational theory on mathematics learning showed that didactic situation theory could be well received by students, students could execute phases that exist in didactic situation theory well. Students were able to work independently or together (groups). The answers given by the students during the test using didactic situation theory varied. Students activeness increased during the learning process from the first meeting to the end of it. Student response to learning by using didaktic situation theory is quite well proven from student questionnaire results.
\end{abstract}

Keywords: Didaktik Situation Theory, Social Arithmetic

\section{PENDAHULUAN}

Soal cerita matematika sangat berperan dalam kehidupan siswa, karena dalam soal cerita tersebut mengandung permasalahan yang sesuai dengan kehidupan seharihari.Misalnya dalam materi aritmatika sosial yang mempelajari untung, rugi, diskon, bruto, netto dan lain sebagainya. Di sisi lain soal cerita matematika bermanfaat untuk melatih kemampuan siswa dalam bernalar, melatih berpikir deduktif dan sistematis, serta memperkuat penguasaan konsep matematika siswa.

Aritmatika sosial adalah salah satu mata pelajaran matematika di Sekolah Menengah Pertama yang memiliki peran penting dalam kehidupan sehari-hari, karena aritmatika sosial adalah materi matematika yang sering kita jumpai dalam kehidupan sehari-hari. 
KONTINU: Jurnal Penelitian Didaktik Matematika

Vol: 2, No.2, Oktober 2018

Masyarakat biasa menerapkan dalam bidang perdagangan dan perbankan. Namun kenyataan yang terjadi walaupun materi pokok tersebut sudah akrab dalam kehidupan siswa tetapi masih banyak siswa yang kurang memahami materi pokok tersebut. Sebagai contoh siswa sering sekali tidak bisa menentukan harga pembelian suatu barang jika harga penjualan dan presentase keuntungan diketahui.

Fakta diatas diperkuat kembali dengan observasi yang menyatakan bahwa persentase penguasaan materi dalam penggunakan konsep operasi hitung \& sifat-sifat bilangan, perbandingan, bilangan berpangkat, aritmetika sosial, barisan bilangan, serta penggunaannya dalam pemecahan masalah di MTs Miftahul Ulum Pendem terbukti hanya 45, $01 \%$ yang menguasai materi tersebut. Artinya dalam hal ini kemampuan siswa dalam menguasai materi aritmatika sosial masih rendah. Kemudian diperkuat kembali oleh Afifah. D. S. N (2013) dalam penelitiannya yang berjudul Identifikasi kemampuan siswa dalam Menyelesaikan Soal Aritmatika Sosial Ditinjau dari Perbedaan Kemampuan Matematika menyimpulkan bahwa banyak siswa yang masih belum benar dalam mengerjakan soal aritmatika social.

Hasil observasi pada pembelajaran matematika yang dilakukan di MTs Miftahul Ulum Pendem Kecamatan Kembang Kabupaten Jepara pada tanggal 10 November 2017 Selain itu, guru sudah menggunakan metode yang beragam, antara lain ceramah, latihan, dan diskusi.Namun metode tersebut belum dikembangkan secara optimal.Selain itu, pembelajaran masih terpaku pada buku pelajaran. Demikian juga dalam proses pembelajaran, siswa belum ditempatkan sebagai subjek belajar yang harus dibekali kemampuan untuk mengkonstruksi pengetahuan secara independen dalam atmosfer pembelajaran inquiri.

Lantas pembelajaran yang seperti apa yang dapatmengatasikesulitan yang dihadapisiswa MTs Miftahul Ulum Pendem khususnya pada materi aritmatika sosial sub bab pembelian, penjualan, untung, rugi, bunga, dan pajak. Pembelajaran yang sederhana yang lebih memusatkan pada siswa sehingga lebih bisa mengembangkan pemikiran siswa.

Pada Pelaksanaannya MTs Miftahul Ulum Pendem sampai saat ini proses pembelajaran yang berpusat pada siswa masih mengalami banyak kendala. Salah satu kendalanya adalah rendahnya kemampuan siswa dalam menyelesaian soal cerita yang ditandai dengan 1) guru cenderung memberikan soal yang mudah yang sesuai dengan rumus atau sesuai dengan contoh yang diberikan di LKS sehingga siswa lebih merasa puas karena sudah bisa mengerjakan. 2) Pembelajaran yang ada di MTs Miftahul Ulum Pendem masih belum berpusat pada siswa, artinya pembelajaran yang mengutamakan kemandirian siswa dalam menyelesaikan permasalahan belum dilaksanakan oleh guru. Sehingga siswa 
KONTINU: Jurnal Penelitian Didaktik Matematika

Vol: 2, No.2, Oktober 2018

dalam menyelesaikan suatu permasalahan cenderung masih bergantung pada guru yang mengajar.

Permasalahan yang sudah dipaparkan, memerlukan solusi dan penanganan yang tepat agar pembelajaran dapat berlangsung dengan baik. Salah satu solusi dan penanganan yang tepat agar pembelajaran berlangsung dengan baik adalah dengan menggunakan teori situasi didaktik. Menurut Artigue (1994), teori situasi didaktik dalam matematika adalah sistem model dan konsep yang bertujuan untuk memodelkan situasi pengajaran sehingga bisa dikembangkan dengan cara yang terkendali.Permasalahan yang sudah diungkapkan dan adanya penelitian yang mendukung salah satunya yaitu Ariatna. Ihsan, Lidinillah. D, dan Hodidjah (2014) menunjukkan bahwa desain didaktis merupakan solusi yang baik yang dapat digunakan dalam pembelajaran matematika. Berawal dari hal tersebut, peneliti mencoba untuk melakukan suatu eksperimen pembelajaran matematika dengan menerapkan pembelajaran yang melibatkan siswa itu aktif, menarik, dan dalam kondisi yang menyenangkan dengan mengangkat tema: Penerapan teori situasi didaktik pada materi aritmatika sosial.

\section{METODE PENELITIAN}

Penelitian ini menggunakan pendekatan kualitatif.Metode penelitian kualitatif adalah metode penelitian yang berlandaskan pada filsafat postpositivisme, digunakan untuk meneliti pada kondisi objek yang alamiah, (sebagai lawannya adalah eksperimen) dimana peneliti adalah sebagai instrumen kunci, pengambilan sampel sumber data dilakukan secarapurposivedan snowball, teknik pengumpulan dengan triangulasi (gabungan), analisis data bersifat kualitatif, dan hasil lebih menekankan makna daripada generalisasi (Sugiyono, 2013). Sampel sumber data dalam penelitian ini dipilih secara purposive sampling yaitu teknik penentuan sampel dengan pertimbangan tertentu (Sugiyono, 2016).

Jenis penelitian ini adalah penelitian desain didaktis (Didactical Design Research).Penelitian yang akan dilaksanakan ini, penulis akan fokus pada masalah yang akan diteliti agar tidak menimbulkan perluasan masalah. Oleh karena itu penelitian hanya akan fokus pada hal-hal berikut:1) Mendiskripsikan penerapan situasi didaktik pada pembelajaran matematika. 2) Hasil tes yang dikerjakan siswa akan dianalisis sesuai dengan teori situasi didaktik. 3) Hasil tes berpusat pada materi aritmatika sosial khususnya pada materi penjualan, pembelian, keuntungan, kerugian dan bunga tunggal.4) Hasil angket respon siswa.

Adapun data yang dikumpulkan dalam penelitian ini adalah: 1) Hasil observasi berupa data kegiatan pembelajaran matematika siswa di kelas dan kegiatan siswa dalam 
KONTINU: Jurnal Penelitian Didaktik Matematika

Vol: 2, No.2, Oktober 2018

mengerjakan soal yang diberikan oleh peneliti. 2) Hasil tes siswa dalam menyelesaikan soal matematika pada materi aritmatika sosial sub bab pembelian, penjualan, keuntungan, kerugian, dan bunga tunggal yang diberikan peneliti. 3) Dokumentasi kegiatan siswa dari awal penelitian hingga akhir penelitian berlangsung. Dokumentasi merupakan bukti pelaksanaan dalam bentuk foto, dokumen hasil pekerjaan siswa dan dokumen pendukung lainnya.

\section{HASIL DAN PEMBAHASAN}

Pengambilan data dimulai dengan mendiskripsikan proses pembelajaran yang telah berlangsung. Kemudian dilanjutkan dengan pembelajaran berdasarkan teori situasi didaktik yaitu pada saat tes berlangsung. Selanjutnya, dilakukan pemberian angket pada seluruh siswa kelas VII B guna untuk mengetahui repon siswa terhadap pembelajaran.

Pertemuan pertama peneliti melakukan kegiatan belajar mengajar dengan menggunakan metode ceramah. Materi yang diajarkan pada pertemuan pertama yaitu tentang penjualan, pembelian, keuntungan, dan kerugian. Pada pertemuan pertama ini guru membagi kelas menjadi 7 kelompok yang terdiri dari 4 orang pada masing-masing kelompok. Secara umum proses pembelajaran pada pertemuan pertama masih ditemui beberapa kendala pada saat pembelajaran. Dikarenakan siswa masih beradaptasi dengan lingkungan, begitupun siswa masih canggung dengan guru yang mengajar karena belum terbiasa. Hal tersebut menyebabkan pada proses pembelajaran kurang maksimal. Namun, siswa sudah memahami materi yang telah dijelaskan oleh guru. Dibuktikan dengan hasil latihan siswa pada saat pembelajaran.

Pertemuan kedua peneliti melakukan kegiatan belajar mengajar dengan menggunakan metode ceramah dan diskusi. Materi yang diajarkan pada pertemuan yaitu tentang presentase keuntungan, dan kerugian serta bunga tunggal. Siswa terlibat secara aktif dalam pembelajaran, dibuktikan dengan guru memberikan kesempatan untuk bertanya tentang apa yang kurang dipahami kepada siswa. Pada pertemuan kedua ini sudah berjalan dengan lancar sesuai dengan alokasi waktu yang ditentukan. Kendala yang terjadi seperti pada pertemuan pertama sudah berkurang. Siswa mulai dapat beradaptasi dengan lingkungan, sehingga siswa mulai antusias mengikuti setiap kegiatan pembelajaran berlangsung.

Keterkaitan antara pertemuan sebelumnya dengan pertemuan ketiga ini yaitu pada pertemuan pertama dan kedua adalah bentuk pemanasan sebagai pendalaman materi yang diberikan oleh guru pada siswa agar siswa tidak merasa canggung dengan diterapkannya teori situasi didaktik pada pertemuan ketiga. Pada pertemuan ketiga ini peneliti 
KONTINU: Jurnal Penelitian Didaktik Matematika

Vol: 2, No.2, Oktober 2018

memberikan tes dan juga angket. Pembelajaran berdasarkan teori situasi didaktik merupakan pengajaran yang menempatkan siswa sebagai inquirer dalam menyelesaikan masalah.

Penerapan teori situasi didaktik pada kelas VII MTs Miftahul Ulum Pendem dalam materi aritmatika sosial mengalami keberhasilan, yang dibuktikan dengan antusias siswa dalam mengikuti pembelajaran yang di dalamnya menggunakan teori situasi didaktik juga baik, begitupun tes yang dikerjakan siswa menunjukkan bahwa dengan teori situasi didaktik siswa menjadi paham materi aritmatika sosial meskipun ada beberapa siswa yang belum tepat dalam mengerjakannya. Hal ini sesuai dengan penelitian yang dilakukan oleh Sarah, Suryadi, dan Fatimah (2017) bahwa teori situasi didaktik merupakan alternatif yang baik yang dapat pada pembelajaran matematika. Selain itu, keberhasilan penerapan teori situasi didaktik juga dibuktikan dengan adanya tahapan fase-fase dalam teori situasi didaktik. Kajian utama dalam didaktik matematik ialah bagaimana guru mengkaji isi pelajaran lalu mentransformasikannya ke dalam situasi pembelajaran guna memfasilitasi siswa meraih pengetahuan dengan lebih baik. Napitapulu dan Kartasasmita (2009) mengemukakan bahwa transformasi yang dilakukan guru berwujud sebuah masalah kontekstual matematik yang menantang siswa melakukan penyelidikan dalam rangka memecahkan masalah tersebut sekaligus membangun pengetahuan baru.

Teori situasi didaktik memiliki 5 fase dalam penerapan pembelajarannya. Fase pertama yaitu fase devolusi, dalam fase ini guru menyajikan masalah untuk siswa dan menjelaskan peraturan dalam menyelesaikan masalah tersebut. Yaitu dengan membagi kelas ke dalam beberapa kelompok. Dalam fase ini, guru juga berperan meyakinkan siswa bahwa mereka mampu mengerjakan secara mandiri maupun secara diskusi atau bersama. Berikut adalah soal tes pada pertemuan ke tiga.

1. Seorang pedagang membeli 1 rim kertas A4 dengan harga Rp 50.000. kertas tersebut dijual secara ecer per 5 lembar. Agar pedagang tersebut untung 20.000, dari hasil penjualan kertas itu berapakah harga ecer per 5 lembar kertas tersebut?

2. Dita menyimpan uang dalam deposito sebesar $\mathrm{Rp} 2.000 .000$, suku bunga pertahunnya adalah 9\% dengan pajak 5\%. Berapakah besar bunga yang diterima Dita selama 1 tahun?

Soal tersebut dibuat tidak sesuai dengan soal yang ada dalam lembar kerja siswa dan guru juga belum pernah memberikan soal tersebut pada siswa. Hal ini bertujuan agar siswa dapat berpikir lebih luas dan mengembangkan pemikirannya secara mandiri maupun secara bersama. Dalam soal nomor 1, ketika menyelesaikan permasalahan tersebut siswa memikirkan kembali bahwa 1 rim itu ada berapa lembar. Kemudian harus membaginya 
KONTINU: Jurnal Penelitian Didaktik Matematika

Vol: 2, No.2, Oktober 2018

dengan eceran yang akan dijual, sedangkan per ecernya adalah 5 lembar. Dengan begitu, siswa dituntut untuk memikirkan kembali materi diluar aritmatika sosial. Konsep tersebut merupakan konsep yang sesuai dengan teori situasi didaktik.

Siswa ketika menyelesaikan permasalahan soal nomor 2, mereka dihadapkan dengan bentuk soal yang bervariasi lagi. Siswa harus benar-benar memikirkan makna antara bunga 9\% dan pajak 5\%. Apakah pajaknya itu dari depositonya atau dari bunganya, ituyang harus benar-benar dipahami. Secra garis besar kesalahan siswa dalam mengerjakan soal nomor 2 terletak pada bagian kesimpulan yaitu bagaimana menentukan bunga dari deposito tersebut. Adapun hasil analisis jawaban tes teori situasi didaktik akan dijelaskan pada sub bab analisis hasil temuan penelitian.

Fase kedua yaitu fase aksi, pada fase ini siswa secara langsung terlibat dalam penyelesaian masalah secara mandiri. Artinya, siswa menyelesaikan permasalahan yang sudah disajikan peneliti secara mandiri tanpa bantuan dari guru maupun teman sebayanya. Fase ini berhasil dilakukan. Namun, masih terdapat beberapa siswa yang mecoba untuk bekerja sama dengan teman sebelah atau mencoba mengerjakan dengan melihat buku panduan mereka.Fase ketiga yaitu fase formulasi, fase dimana siswa bekerja secara kelompok sesuai dengan kelompok yang sudah ditentukan oleh peneliti. Dalam kelompok ini mereka mengevaluasi hasil dari pekerjaan mereka secara individu, kemudian menarik kesimpulan dari pekerjaan masing-masing secara bersama dalam kelompok tersebut. Fase ini berhasil dilakukan para siswa dengan baik.

Fase keempat adalah validasi, dalam fase ini setiap kelompok diminta untuk menguji strategi atau hipotesis mereka dengan cara mereka mempresentasikan hasil diskusi mereka atau kesimpulan yang mereka dapatkan dalam kelompok. Berikut adalah tabel hasil kelompok pada fase 4:

\begin{tabular}{lccc}
\hline Soal nomor 1 & Keterangan & Soal nomor 2 & Keterangan \\
\hline & & & \\
& & Kelompok 1 nomor & Jenis jawaban salah \\
& & 2 & 1 \\
Terdapat 1 jawaban karena & & Kelompok 2 nomor & Jenis jawaban salah \\
secara keseluruhan masing- & Jawaban & 2 & 2 \\
masing kelompok memiliki & benar & Kelompok 3 nomor & Jenis jawaban salah \\
jawaban yang sama & & 2 & 3 \\
& & Kelompok 4 nomor & Jenis jawaban benar
\end{tabular}

\section{Tabel 1. Rekap Hasil Diskusi Kelompok}


KONTINU: Jurnal Penelitian Didaktik Matematika

Vol: 2, No.2, Oktober 2018

Dari hasil diskusi kelompok pada soal nomor 1 seluruh kelompok memiliki jawaban yang sama karena masing-masing kelompok dapat mengaitkan materi aritmatika social dengan satuan. Dari hasil diskusi kelompok masing-masing kelompok memiliki jawaban yang berbeda, 3 di antaranya jawaban salah dan satu di antaranya jawaban yang benar. Setiap kelompok memiliki jawaban yang berbeda karena pemikiran dari anggota setiap kelompoknya berbeda, hal tersebut dikarenakan bentuk soal yang berbeda dan mengecoh sehingga masing-masing kelompok memiliki penafsiran yang berbeda. Kesalahan pada nomor 2 dikarenakan aggota dari masing-masing kelompok kurang memahami betul dengan konsep perpajakan sehingga mereka terkecoh dengan soal yang ada. Adapun bahasan yang lebih lanjut akan dibahas pada materi selanjutnya.

Fase terakhir yaitu fase institusionalisasi, yaitu dimana guru mengumpulkan ide, dari siswa kemudian ditarik kesimpulan.Sebelum guru menyimpulkan, guru melakukan diskusi terhadap siswa kenapa siswa memilih untuk menyimpulkan jawaban tersebut. Dan siswa menjawab bahwa yang mereka pikirkan adalah bunga yang ditanyakan tersebut bunga dari hasil deposito bukan dari pajak. kemudian dalam fase ini, guru menyimpulkan atau mengevaluasi secara bersama-sama dengan siswa kebenaran dari masalah yang telah disajikan oleh guru tersebut. Berikut adalah dialog antara guru dengan siswa.

Dialog pada kelompok 1 soal nomor 2:

Guru : Kenapa kalian memilih dengan cara mengurangi bunga yang diketahui dengan pajak yang diketahui tanpa menyelesaikan hasilnya terlebih dahulu?

Siswa : Karena saya pikir hasil akhirnya akan tetap sama meskipun tanpa penyelesaiannya.

Guru : padahal kan dalam soal tertera suku bunga dengan pajak 5\%, itu artinya pajak adalah milik dari bunganya dan artinya itu kalian mencari hasil bunga terlebih dahulu begitupun dengan pajaknya, baru kalian kurangi hasilnya.

Dialog pada kelompok 2 soal nomor 2:

Guru : Kenapa kalian memilih mengerjakan hanya dari bunganya saja tanpa mengerjakan pajaknya dan mengambil kesimpulan dari bunga tersebut?

Siswa : Karena kan yang ditanyakan adalah bunganya bu bukan pajaknya.

Guru : Kalian perhatikan soalnya, yang diketahui adalah suku bunga pertahunnya adalah $9 \%$ dengan suku pajak 5\%, itu artinya adalah pajak yang dimaksud itu dari bunga tersebut.

Dialog pada kelompok 3 nomor 2:

Guru : Kenapa kalian mencari bunga dan pajaknya dari deposito awal?

Siswa : Karena yang ditanyakan berapa bunganya dan dengan pajak tersebut bu. 
KONTINU: Jurnal Penelitian Didaktik Matematika

Vol: 2, No.2, Oktober 2018

Guru : padahal kan dalam soal tertera suku bunga dengan pajak 5\%, itu artinya pajak adalah milik dari bunganya dan artinya itu kalian mencari hasil bunga terlebih dahulu begitupun dengan pajaknya, hasil dari bunganya kamu kalikan dengan pajaknya 5\%, baru kalian kurangi hasilnya.

Terakhir yaitu peneliti membenarkan atau menarik kesimpulan dari hasil pekerjaan siswa secara bersama-sama dalam kelas.Pada fase ini guru memberikan kebenaran yang sesungguhnya dari hasil presentasi siswa bahwa jawaban yang benar adalah bunga yang diterima yaitu sebesar Rp 171.000 karena pajak yang dimaksud adalah pajak yang dimiliki oleh bunga tersebut.

Teori situasi didaktik mengajarkan siswa untuk mengembangkan pengetahuan yang sudah mereka miliki baik secara mandiri maupun secara bersama. Dalam menyelesaikan permasalahan siswa tidak hanya mengunakan rumus yang sudah ada dalam lembar kerja siswa namun siswa juga dituntut untuk berpikir kembali sebelum menyelesaikan permasalahan dengan menggunakan rumus tersebut. Seperti dalam soal berikut.

1. Seorang pedagang membeli 1 rim kertas A4 dengan harga 50.000. kertas tersebut dijual secara ecer per 5 lembar. Agar pedagang tersebut untung 20.000, dari hasil penjualan kertas itu berapakah harga ecer per 5 lembar kertas tersebut.

Hasil pekerjaan subjek secara keseluruhan pada soal nomor 1 memiliki jawaban yang sama terlihat bahwa siswa dapat memahami permasalahan yang diberikan. Hal ini dapat dilihat pada hasil pekerjaan subjek pada gambar 4.1. Siswa dapat menyelesaikan permasalahan yang diberikan. Siswa dapat menyajikan diketahui dan ditanyakan soal, mampu menyelesaikan permasalahan dengan menentukan berapa banyaknya eceran kertas dalam satu rim, kemudian harga jual kertas dengan benar dan tepat.

Siswa juga mampu membuat kesimpulan dari permasalahan yang diberikan. Subjek penelitian mampu menyelesaikan topik lain matematika dari materi yang dipelajari, yaitu mampu menentukan berapa banyaknya lembar kertas dalam satu rim. Pada soal nomor 1, sebagian besar subjek menyelesaikan permasalahan dengan benar dan tepat. Namun dalam penyelesaiannya beberapa siswa ada yang melewati 1 langkah penyelesainnya meskipun hasil dari penyelesainnya adalah benar.

Aritmatika sosial adalah bagian dari matematika yang mempelajari tentang perhitungan-perhitungan yang digunakan masyarakat dalam kehidupan sehari-hari. Kaitan aritmatika sosial dengan teori situasi didaktik adalah siswa bisa mengembangkan pengetahuannya baik secara mandiri atau bersama yang berkaitan dengan materi aritmatika sosial, karena dalam aritmatika sosial siswa cenderung sulit menyelesaikan soal yang 
KONTINU: Jurnal Penelitian Didaktik Matematika

Vol: 2, No.2, Oktober 2018

berbentuk cerita, sehingga dengan adanya teori situasi didaktik siswa dapat memahami konsep aritmatika sosial sehingga mereka bisa mengembangkan pengetahuannya. Seperti dalam soal yang saya akan paparkan di bawah ini:

2. Dita menyimpan uang dalam deposito sebesar 2.000 .000 , suku bunga pertahunnya adalah $9 \%$ dengan pajak 5\%. Berapakah besar bunga yang diterima dita selama 1 tahun?

Soal yang dipaparkan akan membuat siswa terkecoh dengan adanya pajak 5\%, apakah pajak tersebut dari depositonya ataukah dari bunga pertahunnya. Dari situlah siswa akan mengembangkan pikirannya sehingga nantinya dapat menemukan solusi yang tepat. Meskipun pada dasarnya mereka sudah mengetahui konsep dasar dari aritmatika, akan tetapi ada sesuatu yang baru yang harus mereka pikirkan kembali, disitulah letak situasi didaktiknya ketika siswa harus menyelesaikan suatu permasalahan yang dasarnya mereka sudah mengetahui tetapi ada suatu hal yang baru yang harus mereka pikirkan kembali.

Soal nomor 2 ini, siswa sudah mampu menyajikan yang diketahui, ditanyakan dengan baik dan benar. Namun dalam penyelesainnya ada beberapa siswa yang terkecoh dengan maksud soal, sehingga berpengaruh dalam pengambilan kesimpulan. Ada siswa yang dalam penyelesainnya benar namun dalam pengambilan kesimpulan dia terkecoh dengan pertanyaan soal sehingga dia mengambil kesimpulan dari besar bunganya saja. Ada pula yang hanya menyelesaikan besar bunganya saja tanpa mencari besar pajaknya. Namun, beberapa siswa yang menjawab dengan benar sesuai dengan pedoman penskoran kunci jawaban yang ada.

Soal nomor 2 adalah soal yang menarik yang berhubungan dengan teori situasi didaktik. Karena pada soal ini siswa akan diuji dengan bentuk soal yang berbeda, yang dapat membuat siswa terkecoh. Pada soal nomor 2 ini ada 4 macam jawaban yang berbeda. 3 diantaranya adalah salah, dalam arti siswa benar dalam langkah penyelesaiannya, namunmereka salah dalam menarik kesimpulan dan ada pulayang salah dalam penyelesaiannya juga kesimpulannya. 1 macam jawaban yaitu terselesaikan dengan baik.

Proses pembelajaran selesai, kemudian peneliti membagikan angket respon pembelajaran siswa yang berdasarkan teori situasi didaktik matematika pada materi aritmatika sosial. Siswa mengisi angket respon pembelajaran dan dikumpulkan kepada peneliti. Adapun hasil angket respon pembelajaran digunakan untuk melihat respon siswa terhadap pembelajaran yang berlangsung selama penelitian. Respon siswa terhadap pembelajaran yang berlangsung dengan peneliti menunjukkan sebagian besar siswa memiliki respon yang baik dan tergolong tinggi. Siswa sangat antusias selama proses 
KONTINU: Jurnal Penelitian Didaktik Matematika

Vol: 2, No.2, Oktober 2018

pembelajaran. Bukan hanya terlihat dari angket respon siswa, tetapi juga terlihat dari hasil pengamatan aktivitas siswa.

Berikut ini adalah rekap hasil observasi aktivitas siswa selama penelitian.

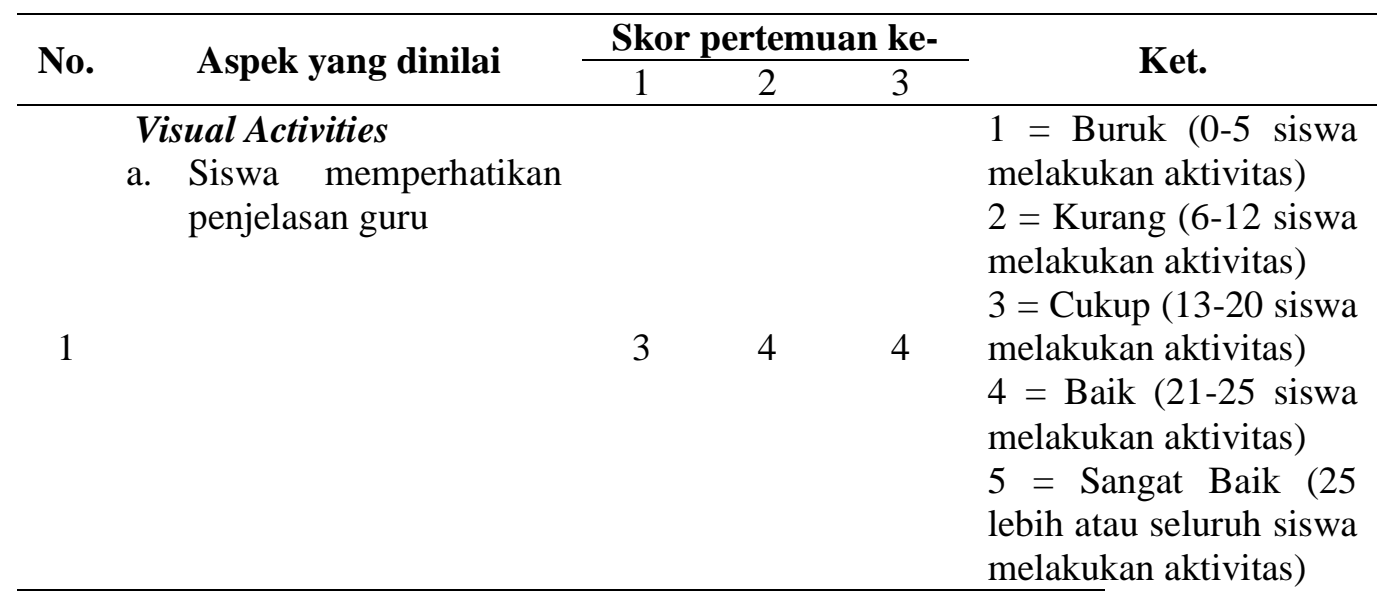

\begin{tabular}{|c|c|c|c|c|}
\hline \multirow[t]{2}{*}{2} & $\begin{array}{ll}\text { Oral Activities } \\
\text { a. } & \text { Siswa bertanya kepada } \\
\text { guru }\end{array}$ & 1 & 1 & 1 \\
\hline & $\begin{array}{l}\text { b. Siwa menanggapi } \\
\text { pertanyaan guru }\end{array}$ & 1 & 2 & 3 \\
\hline 3 & $\begin{array}{l}\text { Writing Activities } \\
\text { a. Siswa mencatat materi } \\
\text { yang sedang diajarkan }\end{array}$ & 3 & 4 & 5 \\
\hline \multirow[t]{2}{*}{4} & $\begin{array}{l}\text { Mental Activities } \\
\text { a. Siswa mengerjakan soal } \\
\text { latihan berdasarkan } \\
\text { konsep yang sudah } \\
\text { dijelaskan }\end{array}$ & 2 & 3 & 4 \\
\hline & $\begin{array}{ll}\text { b. } & \text { Siswa maju } \\
\text { mnegerjakan soal di } \\
\text { papan tulis }\end{array}$ & 1 & 2 & 3 \\
\hline \multirow{2}{*}{5} & $\begin{array}{l}\text { Emotional Activities } \\
\text { a. Siswa menyiapkan alat } \\
\text { tulis dan buku pelajaran }\end{array}$ & 5 & 5 & 5 \\
\hline & $\begin{array}{l}\text { b. Siswa terlihat senang } \\
\text { dan antusias saat belajar } \\
\text { matematika }\end{array}$ & 2 & 3 & 4 \\
\hline
\end{tabular}

Tabel 2. Rekap Hasil Pengamatan Aktivitas Siswa

\begin{tabular}{|c|c|}
\hline Kategori & Rentang nilai \\
\hline Sangat baik & $85 \% \leq \mathrm{p} \leq 100 \%$ \\
\hline Baik & $70 \% \leq p \leq 85 \%$ \\
\hline Cukup baik & $55 \% \leq \mathrm{p}<70 \%$ \\
\hline Kurang baik & $40 \% \leq \mathrm{p}<55 \%$ \\
\hline
\end{tabular}

Tabel 3. Kriteria Skala Penskoran Aktivitas Siswa 
KONTINU: Jurnal Penelitian Didaktik Matematika

Vol: 2, No.2, Oktober 2018

\begin{tabular}{ccc}
\hline Pertemuan Ke- & $\begin{array}{c}\text { Presentase Aktivitas } \\
\text { Siswa }\end{array}$ & Kategori \\
\hline 1 & $45 \%$ & Kurang baik \\
\hline 2 & $60 \%$ & Cukup baik \\
\hline 3 & $72,5 \%$ & Baik \\
\hline
\end{tabular}

Tabel 4. Rekap Presentase Hasil Pengamatan Aktivitas Siswa

Hasil pengamatan yang dilakukan oleh observer untuk mengamati aktivitas siswa selama pembelajaran berlangsung dari pertemuan pertama sampai dengan pertemuan ketiga mengalami kenaikan. Dari yang awalnya hanya 45\%pada pertemuan pertama kemudian $60 \%$ pada pertemuan kedua sampai dengan $72,5 \%$ pada pertemuan ketiga. Hasil pengamatan aktivitas siswa tiap pertemuan menunjukkan peningkatan. Artinya, mulai dari pertemuan pertama sampai dengan pertemuan ketiga yaitu pertemuan terakhir keaktifan siswa mengalami peningkatan. Dari yang awalnya dalam kategori kurang baik sampai akhirnya masuk dalam kategori baik.

Adapun hasil angket respon siswa terhadap kegiatan pembelajaran dengan menggunakan teori situasi didaktik terlihat pada tabel 1. 5 .

\begin{tabular}{cc}
\hline Kategori & Presentase \\
\hline Sangat rendah (SR) & $0 \%$ \\
\hline Rendah (R) & $0 \%$ \\
\hline Sedang (S) & $18,5 \%$ \\
\hline Tinggi (T) & $77,7 \%$ \\
\hline Sangat tinggi (ST) & $3,7 \%$
\end{tabular}

Tabel 5. Hasil Angket Respon Siswa

Berdasarkan data pada tabel 1.5 terlihat bahwa tingkat respon pembelajaran siswa setelah dilaksanakannya proses pembelajaran aritmatika sosial dengan teori situasi didaktik menunjukkan 18, 5\% siswa berada pada tingkat sedang, $77,7 \%$ siswa berada pada tingkat tinggi, dan 3,7\% siswa berada pada tingkat sangat tinggi. Tidak terdapat siswa yang berada pada tingkat rendah dan sangat rendah. Artinya, dengan menggunakan teori situasi didaktik pemahaman siswa, percaya diri siswa, keingintahuan, kemampuan mandiri siswa, kemampuan bersama siswa ataupun apresiasi siswa terlihat sangat baik, dibandingkan dengan hasil wawancara observasi awal yang dilakukan peneliti. 
KONTINU: Jurnal Penelitian Didaktik Matematika

Vol: 2, No.2, Oktober 2018

\section{KESIMPULAN}

Hasil pengamatan aktivitas siswa tiap pertemuan menunjukkan peningkatan. Artinya, mulai dari pertemuan pertama sampai dengan pertemuan ketiga yaitu pertemuan terakhir keaktifan siswa mengalami peningkatan. Dari yang awalnya dalam kategori kurang baik sampai akhirnya masuk dalam kategori baik.Hasil dari angket respon siswa menunjukan bahwa 77,7\% siswa berada pada tingkat tingi, dan 3, 7\% siswa berada pada tingkat sangat tinggi. Artinya, dengan menggunakan teori situasi didaktik pemahaman siswa, percaya diri siswa, keingintahuan, kemampuan mandiri siswa, kemampuan bersama siswa ataupun apresiasi siswa terlihat sangat baik, dibandingkan dengan hasil wawancara observasi awal yang dilakukan peneliti.Subjek penelitian ini adalah 28 siswa kelas VII B Semester 2 tahun ajaran 2017/2018 di MTs Miftahul Ulum. Penelitian ini diawali dengan observasi selama 2 jam pelajaran dan dilanjutkan dengan 3 pertemuan, 2 pertemuan dengan metode ceramah dan 1 pertemuan dengan teori situasi didaktik.Hasil penelitian dengan menggunakan teori situasi didaktik pada pembelajaran matematika menunjukkan bahwa teori situasi didaktik dapat diterima dengan baik oleh siswa, siswa dapat melaksanakan fase-fase yang ada dalam teori situasi didaktik dengan baik meskipun terdapat beberapa kendala dalam pelaksanaannya. Siswa mampu mengerjakan secara mandiri maupun secara bersama (kelompok). Hasil kerjaan pada saat tes dengan menggunakan teori situasi didaktikpun bervariasi. Dari 2 soal yang diberikan oleh guru, secara keseluruhan soal nomor satu memiliki jawaban yang sama, sedangkan soal nomor 2 terdapat 4 bentuk jawaban yang berbeda. 3 diantaranya adalah jawaban salah dan 1 diantaranya adalah jawaban yang benar. Kesalahan dari 3 kelompok pada soal nomor 2 secara keseluruhan karena siswa kurang memahami konsep tentang pajak dengan baik.

\section{DAFTAR PUSTAKA}

Afifah, D. S. N. (2013). Identifikasi Kemampuan Siswa Dalam Menyelesaikan Soal Aritmatika Sosial Ditinjau Dari Perbedaan Kemampuan Matematika (Identify The Student's Ability In Solving The Social Aritmatic Problem Depend From Difference Mathematic. 1(1), 1-2.

Ariatna, I., Lidinillah, D. A. M., \& Hodidjah, H. (2014). Desain Didaktis Bahan Ajar Koneksi Matematika pada Konsep Luas Daerah Trapesium. PEDADIDAKTIKA: Jurnal Ilmiah Pendidikan Guru Sekolah Dasar, 1(1). 1-10

Artigue, M. (1994).Didactical engineering as a framework for the conception of teaching products. Didactics of mathematics as a scientific discipline,13, 27-39. 
KONTINU: Jurnal Penelitian Didaktik Matematika

Vol: 2, No.2, Oktober 2018

Napitapulu, E. Elvis \& Kartasasmita, Bana. G. 2009. Situasi Didaktik dalam Pembelajaran Matematika Berbasis Masalah. Jurnal Didaktik Matematika. 1(2). 1-8.

Sarah, S., Suryadi, D., \& Fatimah, S. (2017). Desain Didaktis Konsep Volume Limas Pada Pembelajaran Matematika Smp Berdasarkan Learning Trajectory. Journal of Mathematics Education Research, 1(1).

Sugiyono.(2013). Metode Penelitian Pendidikan Pendekatan Kuantitatif, Kualitatif, dan $R \& D$. Bandung : Alfabeta.

Sugiyono. (2016). Metode Penelitian Pendidikan Pendekatan Kuantitatif, Kualitatif, dan $R \& D$. Bandung: Alfabeta. 